\title{
PENGEMBANGAN MODEL STRUKTUR PENGENDALIAN INTERN BERBASIS MODAL SOSIAL UNTUK MENCEGAH KEBANGKRUTAN LEMBAGA PERKREDITAN DESA (LPD) DI BALI
}

\author{
Anantawikrama Tungga Atmadja, Nyoman Ari Surya Darmawan, \\ Nyoman Trisna Herawati \\ Jurusan Akuntansi, Fakultas Ekonomi dan Bisnis \\ Universitas Pendidikan Ganesha, Singaraja-Bali \\ E-mail: anantawikramatunggaatmadja@gmail.com, \\ arisurya.dharmawan@gmail.com, aris_herawati@yahoo.co.id
}

\begin{abstract}
Abstrak
Sebagai lembaga bentukan desa pakraman, selain memiliki fungsi bisnis LPD juga memiliki fungsi sosial untuk memajukan perekonomian desa pakraman beserta seluruh krama-nya. Fungsinya yang penting ini mengakibatkan LPD harus dihindarkan dari permasalahan keuangan yang dapat berujung pada kebangkrutan. Berbeda dengan lembaga keuangan lainnya selain mempergunakan tata aturan organisasi formal, LPD mempergunakan modal sosial yang dimiliki oleh desa pakraman sebagai basis aktivitas operasionalnya. Untuk itu, penelitian ini bertujuan untuk membangun model srtuktur pengendalian intern berbasis modal sosial yang dapat diterapkan pada seluruh LPD di Bali yang dibagi menjadi tiga tahapan penelitian. Pada tahapan pertama ini akan diinventarisir modal sosial apa yang dapat dimanfaatkan untuk memperkuat struktur pengendalian LPD dengan mengetahui, 1) alasan desa pakraman membentuk LPD, 2) hubungan antar para pemangku kepentingan di LPD, dan 3) bentuk penyertaan modal sosial dalam struktur pengendalian intern LPD. Penelitian ini dilakukan dengan metode penelitian kualitatif pada 18 LPD di seluruh kabupaten dan kota madya di Bali. Data dikumpulkan dengan wawancara, observasi partisipasi, dan studi dokumentasi yang selanjutnya dianalisis berdasarkan kerangka teoritik yang telah disusun sebelumnya. Hasil penelitian menujukkan bahwa 1) LPD didirikan berdasarkan instruksi penguasa supra desa sekaligus merupakan kebutuhan krama desa pakraman, 2) pola hubungan antar stakeholder berbasis modal sosial yang dilandasi ideologi Tri Hita Karana, serta 3) modal sosial yang berperan dalam aktivitas operasional sekaligus pelaksanaan struktur pengendalian intern LPD adalah trust, jaringan sosial, dan pranata sosial. .
\end{abstract}

Kata kunci: Lembaga Perkreditan Desa, Model Struktur Pengendalian Intern, Modal Sosial, Tri Hita Karana, Kebangkrutan 


\begin{abstract}
As an institution formed by Desa Pakraman, besides having a business function LPD also has a social function to promote the economy of Desa Pakraman and its members. This important functions derive LPD should be avoided from the financial problems that can lead to bankruptcy. Compared to other financial institutions, LPD is ruled by using the formal organization and importantly social capital belonged to Desa Pakraman as the basis of operational activities. Therefore, this study aims to develop a model of internal control structure based on social capital that can be applied to the entire LPD in Bali. This study is divided into three stages of research. In the first stage it will be inventoried what social capital can be used to strengthen the structures of LPD's control by knowing: 1) the reason of Desa Pakraman in building an LPD, 2) the relationship among the stakeholders in LPD, and 3) form of social capital share in the LPD's internal control structure. This research was conducted using qualitative method at 18 LPDs in all regencies in Bali. Data were collected through interviews, participatory observation and documentation study. It was then analyzed based on the theoretical framework that has been developed previously. The results showed that 1) LPD was established based on instruction of the ruler of the supra-villages as well as the need of Desa Pakraman, 2) the pattern of relationships among stakeholders was based on social capital with the ideology of Tri Hita Karana, and 3) the social capital involved in operational activities and the implementation of internal control structure of LPD is trust, social networks, and social institutions.
\end{abstract}

Keywords: Lembaga Perkreditan Desa (LPD), model of internal control structure, social capital, Tri Hita Karana, bankruptcy.

\section{PENDAHULUAN}

LPD merupakan lembaga keuangan milik desa pakraman yang bertujuan untuk meningkatkan kesejahteraan krama desa pakraman. Dalam rangka mewujudkan misinya, manajemen LPD harus dapat melakukan aktivitas operasionalnya dengan baik. Hal ini dapat dilakukan antara lain dengan menciptaan suatu struktur pengendalian intern yang memadai. Struktur pengendalian intern yang memadai sangat diperlukan karena struktur ini memiliki tujuan untuk; 1) menghasilkan laporan keuangan yang dapat dipercayai, 2) menciptakan kepatuhan organisasi akan undang-undang dan peraturan yang berlaku serta, 3) meningkatkan efektivitas dan efisiensi operasional organisasi (Hartadi, 1999 dan Munawir, 2005). Untuk mewujudkan struktur pengendalian yang memadai, LPD harus dapat mensinergikan unsurunsur pengendalian intern yang terdiri dari: 1) lingkungan pengendalian organisasi, 2) pertimbangan resiko, 3) aktivitas pengendalian, 4) informasi dan komunikasi, serta 5) aktivitas monitoring (Rama and Jones, 2006: 105).

LPD sebagai sebuah lembaga subordinat desa pakraman, menimbulkan implikasi bahwa segala aktivitas akan dipertanggungjawabkan kepada desa pakraman. Hal ini dapat dilihat pada struktur organisasi LPD, yang menempatkan desa pakraman yang dipimpin oleh ketuanya yang disebut bendesa desa pakraman, yakni sebagai lembaga yang memiliki peranan menyerupai dewan komisaris dalam perusahaan yang berbentuk perseroan terbatas. Struktur organisasi 
ini menyebabkan desa pakraman memegang peranan penting dalam penentuan kebijakan LPD, termasuk di dalam menciptakan sebuah lingkungan pengendalian yang dapat menunjang berjalannya pengendalian intern yang memungkinkan tercapainya tujuan LPD dengan baik (Bodnar and Hopwood, 2004). Pelaksanaan pengendalian LPD memanfaatkan apa yang disebut modal sosial. Penyertaaan modal sosial dalam pengendalian intern, berlaku bagi segenap manajemen, maupun nasabah LPD. Hal ini tidak bisa dilepaskan dari adanya kenyataan bahwa baik nasabah maupun manajemen LPD merupakan krama desa pakraman, sehingga mereka harus tunduk kepada awig-awig desa pakraman. Hal ini mengakibatkan, setiap penyimpangan yang terjadi, siapapun yang melakukannya, dapat dikenai sanksi adat. Selain itu, LPD sebagai lembaga perkreditan formal menggunakan pula mekanisme pengendalian intern berbasis akuntansi yang diterapkan pada entitas bisnis pada umumnya. Jadi, ada dua mekanisme pengendalian yang berlaku secara simultan pada LPD di Bali, yakni pengendalian yang mengikuti kaidahkaidah struktur pengendalian intern, dan yang lainnya adalah pengendalian yang bertumpu pada penggunaan modal sosial yang dimiliki oleh desa pakraman. Pengendalian ini ternyata dapat membuat LPD bisa berjalan dengan baik.

Kebijakan LPD mengawinkan pranata tradisional dan pranata modern dalam rangka membangun struktur pengendalian internnya mengakibatkan banyak LPD yang berkembang dengan baik. Salah satu contoh adalah ketika LPD menghadapi masalah kredit macet yang dapat mengganggu kelangsungan bisnis mereka. LPD berhasil menyelesaikannya secara swadaya dan dalam waktu yang relatif singkat. Kondisi ini berbeda dari bank misalnya, yang jika mereka menghadapi masalah kredit macet penyelesainnya sangat ruwet, bahkan sering berlarut-larut. Contoh lain adalah tingginya tingkat kepatuhan karyawan atas sistem akuntansi serta prosedur-prosedur pengendalian yang telah diterapkan oleh pihak manajemen. Tingginya tingkat kepatuhan ini menjadikan LPD sangat jarang mengalami kerugian akibat penyelewengan yang dilakukan oleh karyawannya. Kondisi ini menunjukkan bahwa di balik keberadaan LPD banyak aspek yang menarik untuk dikaji agar keberadaan LPD terpahami secara jelas dan utuh.

Penelitian ini dilakukan pada 18 LPD di delapan kabupaten dan 1 kodya di seluruh Bali. Kedelapan belas LPD itu adalah: 1) LPD Kuta; 2) LPD Pecatu; 3) LPD Sumber Kima; 4) LPD Pejarakan; 5) LPD Kesiman; 6) LPD Padang Sambian; 7) LPD Bedha; 8) LPD Kediri; 9) LPD Peliatan; 10) LPD Padang Tegal; 11) LPD Sibetan; 12) LPD Duda; 13) LPD Gelgel; 14) LPD Jungut Batu; Nusa Penida; 15) LPD Metra; 16) LPD Tiga; 17) LPD Penyaringan; dan 18) LPD Asah Duren.

Seluruh LPD yang dijadikan lokasi penelitian memiliki kemampuan dalam menggerakkan perekonomian masyarakat. Kemampuan ini ditunjukkan dengan tingginya tingkat penyaluran kredit kepada masayarakat disertai dengan tingkat kolektibilitasnya yang tinggi. Saat ini, kedelapan belas LPD ini telah menjadi lembaga keuangan utama bagi segenap krama desa pakraman. 
Selain itu, hampir tidak terdapat penyelewengan yang dilakukan oleh manajemen maupun karyawan. Hal ini juga menunjukkan bahwa struktur pengendalian intern yang dimiliki kedelapan belas LPD ini bekerja dengan baik. Kondisi ini menjadi menarik untuk diamati agar pemahaman yang diperoleh menjadi semakin jelas.

Selain kepemilikan asset serta skala operasi, kedelapan belas LPD ini memiliki pula variasi dalam hal karakteristik masyarakat yang dilayaninya. Terdapat desa pakraman yang berlokasi di perkotaan, dan pedesaan. Dilihat dari mata pencaharian utama krama terdapat berbagai variasi pula, yakni sebagai petani, nelayan, PNS, wirausahawan, dll. Perbedaan karakteristik masyarakat yang dikaji akan memberikan peluang untuk memperoleh gambaran yang lebih bervariasi atas lingkungan pengendalian yang melingkupi suatu organisasi. Lingkungan pengendalian yang dimaksud adalah pengaruh lingkungan terhadap organisasi dalam merancang serta mengaplikasikan struktur pengendalian internnya (Bodnar and Hopwood, 2004).

Berdasar dari uraian di atas dapat dilihat bahwa kedelapan belas LPD yang dijadikan lokasi penelitian merupakan lembaga keuangan yang mengalami perkembangan yang pesat. Kondisi ini dapat dilihat dari perkembangan asset yang dimilikinya serta posisinya yang tetap menjadi lembaga keuangan utama bagi krama desa pakraman di tengah persaingan yang sedemikian ketat dari lembaga keuangan lainnya. Apa yang mereka capai bukan sesuatu yang mudah, mengingat bahwa sebelumnya LPD tersebut hampir saja bangkrut, karena adanya kredit macet. Namun setelah mereka berhasil mengatasi masalahnya, LPD tersebut bisa berkembang dengan baik.

Keberhasilan ini menunjukkan kemampuan LPD tersebut dalam memanfaatkan struktur pengendalian intern dalam menciptakan efesiensi serta efektivitas operasional sehingga tujuan organisasi dapat terpenuhi. Sebagai lembaga keuangan yang juga memiliki dimensi tradisional, tujuan organisasi tidaklah semata-mata mengejar laba. Keberhasilan LPD, termasuk penerapan pengendalian di dalammnya, juga dinilai dari seberapa besar kemampuan LPD dalam meningkatkan kesejahteraan masyarakat sesuai dengan ideologi Tri Hita Karana yang dianut oleh masyarakat Bali. LPD sangat terkait dengan desa pakraman yang merupakan basis pemeliharaan modal sosial pada masyarakat Bali. Karena itu, tata aturan yang berlaku pada LPD, tidak bisa pula dilepaskan dari modal sosial yang dimiliki oleh desa pakraman. Dengan adanya kenyataan ini maka ada beberapa masalah penelitian yang menarik untuk dikaji. Hal ini dapat dirumuskan dalam pertanyaan penelitian sebagai berikut: 1) Mengapa krama desa pakraman pada 18 desa pakraman ini membentuk Lembaga Perkreditan Desa (LPD)?; 2) Bagaimana struktur organisasi LPD yang mengatur hubungan LPD dengan pihak-pihak yang menjadi stakeholder-nya?; 3) Bagaimana bentuk penyertaan modal sosial dalam struktur pengendalian intern LPD?

Jurnal IImu Sosial dan Humaniora |786 


\section{METODE}

Penelitian dilakukan dengan metode kualitatif. Fokus penelitian ini adalah pengungkapan makna dibalik fenomena. Informan penelitian adalah pengurus LPD, pengurus desa pakraman, nasabah LPD, serta pengurus desa dinas.

Melalui wawancara dengan diperoleh tacit knowledge dari informan tentang permasalahan yang dikaji dalam penelitian. Selain hasil wawancara, data lain dalam penelitian ini adalah hasil obeservasi, dan studi dokumentasi.

Data dianalisis dengan teknik analisis data interaktif (Miles dan Huberman, 1992). Proses analisis dilakukan secara ulang alik dimulai dari pengumpulan data, reduksi data jika diperlukan, penyajian data, dan penarikan kesimpulan. Proses ini dilakukan secara terus menerus hingga menghasilkan pemahaman yang holistik dan kaya makna.

\section{HASIL DAN PEMBAHASAN}

Pendirian LPD ini tidak dapat pula dilepaskan dari kebijakan pemerintah Propinsi Bali yang didukung oleh Pemerintah Kabupaten. Hal ini dilakukan dengan memberikan suntikan dana sebesar Rp. 2.000.000,00 kepada masing-masing desa pakraman untuk membangun LPD-nya masing-masing. Selain melalui bantuan pendanaan, dukungan pemerintah diwujudkan pula dengan menyusun Peraturan Daerah yang mengatur pelaksanaan lembaga keuangan ini.

Dari berbagai kebijakan ini tampak jelas bahwa pemerintah memposisikan dirinya sebagai patron dalam tata budaya paternalistk (Atmadja, 1998). Pemerintah memposisikan diri sebagai
Bapak dan harus mengayomi desa pakraman sebagai anaknya. Sikap mengayomi inilah yang menjadi dasar bagi tindakan kemurahan hati yang berbentuk pemberian modal awal bagi pendirian LPD.

Pada sisi yang lain, desa pakraman dalam perspektif budaya paternalistik memiliki kewajiban yang sama untuk melaksanakan kebijakan yang sudah digariskan oleh patronnya (Atmadja, 1998;). Penerimaan kebijakan ini terkait pula dengan landasan agama Hindu yang dianut oleh mayoritas penduduk di Bali yang mengajarkan sikap hormat kepeda pemerintah yang disebut dengan guru wisesa. Dengan demikian, disadari maupun tidak, masyarakat atau krama desa pakraman diharapkan untuk mengikuti harapan dari pemerintah.

Selain adanya perintah halus dari atasan dalam bentuk pemberian permodalan maupun dukungan tata aturan pendirian LPD tidak dapat pula dilepaskan dari adanya kebutuhan masyarakat akan kredit. Hal ini berkaitan erat dengan pemaknaan mereka terhadap LPD dalam konteks pemenuhan kebutuhan dasar fisiologis, psikologis, sosial, dan kultural. Pemenuhan kebutuhan dasar itu sangat memerlukan barang dan atau jasa, yang sebagian besar didapat lewat pasar. Hal ini sejalan dengan semakin kuatnya pengaruh sistem ekonomi pasar pada masyarakat.

Lebih-lebih dengan semakin kuatnya pengaruh sistem ekonomi kapitalisme global maka ketergantungan masyarakat terhadap sistem ekonomi pasar menjadi semakin kuat pula. Globalisasi mengakibatkan masyarakat pedesaan mengalami transformasi sosial, yakni dari masyarakat agraris 
kolektivistik kea rah masyarakat yang menganut budaya pasar (Piliang, 2004; Chaney, 1996; Bungin, 2001). Budaya pasar mengakibatkan masyarakat sulit membedakan antara kebutuhan dan keinginan, maka kekurangan uang sulit dihindarkan (Lury, 1998; Lull, 1993). Apalagi adanya kegiatan yang wajib dilakukan karena terlegitimasi oleh agama, misalnya penyelenggaraan ritual - kebutuhan kultural, maka kepentingan akan uang menjadi lebih mendesak lagi. Untuk memenuhi kepentingan warga desa akan uang tunai, peran lembaga perkreditan, termasuk LPD, menjadi sangat penting. Selain itu, dalam masyarakat yang semakin individual pinjam meminjam antaranggota masyarakat semakin sulit untuk dilakukan terutama ketika pinjammeminjam ini terjadi dalam jumlah yang besar. Di luar LPD, masih banyak lembaga perkreditan lainnya, misalnya bank dan koperasi simpan pinjam. Dalam konteks ini, apakah mereka memilih LPD atau tidak, sangat ditentukan oleh pertimbagan rasional dan atau pemaknaan mereka terhadap LPD.

Prosedur peminjaman dana di LPD relatif lebih mudah dibandingkan dengan lembaga keuangan lainnya. Selain itu, karena pengurus LPD merupakan orang-orang yang berasal dari desa yang sama maka modal sosial dalam bentuk jaringan sosial akan membuat krama yang mempergunakan jasa LPD akan merasa lebih nyaman dan memilih LPD dibandingkan lembaga keuangan lainnya. Hal ini menjadikan alasan pendirian LPD tidak semata-mata karena LPD memiliki nilai ekonomis tapi juga makna sosial budaya. Karena inilah krama desa pakraman memilik gairah yang besar dalam mendirikan LPD.

LPD sebagai lembaga perkreditan formal memiliki struktur, yakni Ketua LPD, Tata Usaha, dan Kasir. Secara struktural LPD terkait pula dengan berbagai stakeholder, yakni krama desa pakraman yang diwakili oleh bendesa desa pakraman yang berperan tak ubahnya sebagai komisaris, nasabah dengan serangkaian kebutuhannya, dan badan pembina, yakni pemerintah yang diwakili oleh BPD. Dalam melakukan perannya, mereka berkomunikasi atau berinteraksi dengan mengikuti tata aturan yang berlaku. Didalamnya mencakup modal sosial (serangkaian nilai dan norma informal milik kelompok yang mendorong kerja sama) dan struktur pengendalian intern akuntansi. Jika dicermati, modal sosial berkaitan erat dengan ideologi yang berlaku pada masyarakat Bali, yakni Tri Hita Karana. Ideologi ini menekankan pada pencapaian masyarakat sejahtera berlandaskan pada hubungan harmonis antara manusia dengan Tuhan (Parhyangan), manusia dengan sesama manusa (Pawongan) dan manusia dengan alam (Palemahan).

Demi mewujudkan cita-cita ideal ini maka masing-masing pihak menempatkan sumber daya yang dimilikinya dalam aktivitas operasional LPD. Desa pakraman memasukkan sumber daya manusia, finansial, material, teknologi, dan informasi. Dari investasinya ini, desa pakraman akan memperoleh jaminan sosial dan ekonomi dari LPD. Kondisi ini menunjukkan bahwa hubungan antara desa pakraman dan LPD memiliki jaringan kepentingan ekuitas, pasar, dan kekuasaan. Kepentingan ekuitas 
berkaitan dengan berbagai sumber daya ekonomi yang diinvestasikan oleh desa pakraman pada LPD. Kepentingan pasar terkait dengan pada kenyataanya, secara kelembagaan nasabah utama dari setiap LPD adalah krama desa pakraman. Kepentingan kekuasaan bertalian dengan status LPD sebagai milik desa pakraman. Kondisi ini memiliki implikasi politis bahwa desa pakraman memiliki kekuasaan terhadap LPD baik secara struktural maupun kultural.

Selain desa pakraman, stakeholder LPD lainnya adalah Pemerintah Propinsi dan Kabupaten/Kodya termasuk berbagai organ terkait yang dibentuknya seperti Lembaga Pemberdayaan Lembaga Perkreditan Desa (LPLPD). Pemerintah menginvestasikan sumber daya finansial kepada LPD pada saat LPD didirikan. Sumber daya finansial tidak saja bermafaat dalam menggerakkan aktivitas operasional LPD namun juga mendorong kepercayaan krama desa pakraman kepada LPD. Sumber daya finansial menujukkan dukungan pemerintah kepada LPD yang menjadikan tiadanya alasan bagi krama untuk tidak menaruh kepercayaan yang sama.

Sumber daya lain yang diinvestasikan oleh pemerintah adalah sumber daya informasi yang berupa tata aturan yang disusun untuk mengatur aktivitas operasional LPD. Tata aturan ini sangat bermanfaat dalam menunjang keberhasilan LPD. Selain itu, keberadaan tata aturan juga semakin meningkatkan keyakinan kepada bahwa pihak-pihak yang berinteraksi dengan LPD bahwa LPD akan dikelola dengan baik. Tata aturan menjadi indikator penentu sejauh mana efektivitas pengelolaan LPD oleh pengurusnya. Adanya peranan Pemerintah dalam menyusun tata aturan ini menjadikan Pemerintah memiliki kekuasaan terhadap LPD. Hal ini membuat antara LPD dan Pemerintah dapat dikatakan memiliki jaringan kepentingan kekuasaan.

Jaringan kepentingan kekuasaan ini juga ditunjukkan dengan adanya pembinaan dan pengawasan secara berkelanjutan oleh Pemerintah kepada LPD. Pembinaan dan pengawasan ini dilakukan oleh organ yang dibentuk pemerintah yakni Lembaga Pemberdayaan Lembaga Perkreditan Desa (LPLPD). Melalui pembinaan dan pengawasan ini dapat diketahui katagorisasi LPD yang tergolong sehat, cukup sehat, kurang sehat, atau tidak sehat. Katagori ini akan dapat dipakai dasar oleg Gubernur dan Bupati/Walikota untuk menjalankan kekuasaanya yakni melakukan pembinaan kepada LPD dengan kinerja yang kurang baik.

Selain jaringan kepentingan kekuassan hubungan antara pemerintah dan LPD juga merupakan jaringan kepentingan ekuitas dan pasar. Kepentingan ekuitas selain terkait dengan modal yang ditamkan oleh pemerintah juga disebabkan oleh kewajiban pemerintah - melalui Bank Pembangunan Daerah (BPD) Bali untuk memberikan bantuan jika LPD mengalami kesulitasn likuiditas. Pada sisi sebaliknya jika LPD mengalami kelebihan likuiditas maka LPD wajib menyimpannya di BPD Bali. Kondisi ini menjelaskan bahwa antara Pemerintah dan LPD memiliki jaringan kepentingan pasar.

Jurnal IImu Sosial dan Humaniora |789 
Modal sosial dan struktur pengendalian intern berfungsi sebagai resep bertindak bagi aktor-aktor yang terlibat dalam kegiatan LPD sehingga LPD bisa mewujudkan sasarannya, yaitu memperoleh laba dan mempertahankan kelangsungan hidupnya. Kelangsungan hidup suatu lembaga, termasuk LPD memerlukan kontrol intern. Sebagaimana tampak pada bagan LPD terkait dengan desa pakraman. Dia tak ubahnya sebagai komisaris dan sekaligus juga menanamkan modal sosial ke dalam LPD. Bahkan, warga desa pakraman menanamkan pula modal uang pada LPD. Sejalan dengan itu maka peran desa pakraman yang diwakili oleh bendesa desa pakraman dalam penyelenggaraan kontrol intern terhadap LPD sangat penting.

Selain kontrol intern di antara aktoraktor yang duduk dalam struktur manajemen LPD, maka desa pakraman, tidak saja ikut melakukan kontrol intern, tetapi bisa pula mengenakan sanksi adat terhadap orang-orang, baik staf manajemen LPD maupun nasabah yang melakukan penyimpangan. Ada berbagai pilihan sanksi adat yang bisa dikenakan - tergantung pada berat ringannya penyimpangan, yakni teguran, peringatan, denda, kasepekang, pelarangan menggunakan fasilitas desa pakraman (pura, kuburan, karang paumahan desa), dan pengusiran. Belum terhitung lagi adanya sanksi sosial dari warga desa pakraman dalam bentuk gunjingan dan cemohan. Namun, mengingat bahwa LPD adalah lembaga perkreditan yang bersifat formal, maka seperti yang tampak pada bagan, LPD tunduk pula pada struktur pengendalian intern.
Hal ini harus dipatuhi oleh staf manajemen LPD dalam melaksanakan aktivitas bisnisnya dan berhubungan dengan nasabah maupun krama desa pakraman - bendesa desa pakraman. Penerapan kontrol intern formal tidak bisa pula dilepaskan dari peran badan pembina. Dia tidak saja memberikan masukan dalam bentuk ideasional, material, dan finansial - suntikan modal, tetapi juga memberikan pengawasan agar ketentuan yang berlaku bisa dipatuhi oleh semua pihak yang terkait. Pada akhirnya efektivitas perpaduan struktur pengendalian intern dan modal sosial dapat dilihat dari kemampuannya dalam membantu organisasi dalam mencapai tujuannya.

Berdasarkan hasil temuan kancah dapat ditemukan sembilan unsur modal sosal yang berperanan dalam penguatan struktur pengendalian intern LPD. Kesembilan unsur modal sosial ini yakni; 1) kejujuran, 2) sikap egaliter, 3) kerjasama, 4) solidaritas 5) toleransi, 6) kemurahan hati, 7) partisipasi, 8) pertukaran timbal balik, dan 9) keadilan. Kesembilan unsur ini diterapkan secara bervariasi di kedelapan belas LPD yang dijadikan lokasi penelitian.

Kejujuran dapat ditunjukkan dengan upaya terus menerus dari Kepala LPD, karyawan, dan badan pengawas untuk terus menerus melakukan pengendalian diri agar dapat memelihara kejujuran dalam mengelola LPD. Nilai kejujuran menjadi penting karena pengelola LPD merasa bahwa LPD secara niskala merupakan mili Ida Bhatara Sesuhunan di Desa Pakraman masing-masing. Hal ini menjadikan kejujuran adalah hal yang mutlak agar tidak mencederai hubungan mereka dengan Ida Bhatara Sesuhunan.

Jurnal IImu Sosial dan Humaniora |790 
Sikap egaliter tercermin dari adanya keyakinan bahwa LPD adalah milik bersama segenap krama desa pakraman. Keyakinan ini membuat pengurus LPD yang terdiri dari Kepala, Tata Usaha dan Kasir tidak merasa lebih tinggi dengan staff yang lain. Kondisi yang sama terjadi pula pada anggota badan pengawas. Meskipun mereka memiliki tugas untuk mengawasi kinerja LPD namun mereka tidak merasa berada pada posisi yang lebih berkuasa dari para pengurus LPD. Hal ini menjadikan terciptanya iklim kerja yang kondusif karena telah terjadi kerjasama antarsesama pengurus sehingga aktivitas operasional LPD dapat terselenggara dengan baik.

Modal sosial selanjutnya yang memiliki peranan penting adalah toleransi. Sikap solidaritas ini didasari oleh adanya empati antar sesama krama. Kondisi ini menjadikan jika seorang krama berada pada kondisi yang kesulitan maka seluruh anggota krama lainnya akan berusaha membantu. Kesadaran ini akan melahirkan modal sosial lainnya yakni kemurahan hati. Kemurahan hati ini tercermin dari kebijakan LPD untuk memberikan bantuan jika ada krama yang mengalami kesulitan keuangan dikarenakan adanya kematian, keluarga yang sakit, atau kebutuhan sekolah anak. Meskipun krama yang memerlukan pendanaan tidak memenuhi persyaratan pemberian kredit namun jika krama yang bersangkutan dikenal memilik sikap yang jujur maka kredit bisa disalurkan. Kondisi ini melahirkan modal sosial berupa toleransi. Meskipun tidak mengikuti tata aturan yang baku namun kredit seperti ini jarang mendatangkan masalah karena nasabah juga memiliki sikap solidaritas yang sama. Debitur ikut merasakan kesulitan pengurus jika terdapat kredit macet sehingga mereka berupaya untuk membayar cicilan tepat waktu untuk menghindari kredit macet yang dapat menyulitkan pengurus.

Sebagai lembaga keuangan milik desa pakraman, LPD merupakan perwujudan aspek modal sosial yang penting yakni partisipasi. Partisipasi dapat ditunjukkan dari proses rekrutmen pegawai yang melibatkan krama desa pakraman melalui pengurus desa pakraman (proses administrasinya) maupun krama secara keseluruhan melalui sangkep atau rapat desa pakraman. Sangkep merupakan lembaga tertinggi yang memutuskan apakah seseorang dapat diterima menjadi pengurus atau tidak. Dalam sangkep ini berbagai hal yang positif maupun negatif atas seorang calon dikemukakan secara terbuka sehingga pilihan dapat dilakukan secara obyektif.

Rekrutmen karyawan juga dilakukan dengan memperhatikan partisipasi dari masing-masing banjar. LPD akan memperhatikan porsi keterwakilan masing-masing banjar dalam kepengurusan LPD sepanjang calon tersebut memiliki kompetensi yang layak. Selain itu, aspek partisipasi terlihat pula dalam aktvitas pengawasan LPD. Segenap krama melakukan pengawasan secara informal terhadap kinerja pengelola LPD. Jika pengelola LPD memiliki kinerja yang baik maka mereka akan mendapatkan pujian dari krama. Namun sebaliknya, jika mereka menunjukkan kinerja yang buruk maka mereka akan digunjingkan bahkan pada beberapa kasus krama tidak akan segan-segan menegur pengurus LPD

Jurnal IImu Sosial dan Humaniora |791 
yang menujukkan kinerja yang tidak baik. Pengawasan informal sebagai wujud partisipasi krama ini membuat pengurus LPD senantiasa berupaya untuk menunjukkan kinerja terbaiknya.

Modal sosial lainnya adalah pertukaran timbal balik. Pertukaran timbal balik ini tidak dapat dilapaskan dari nilai agama Hindu yakni tat twam asi. Nilai ini secara harfiah berarti "itu adalah kau" atau dengan kata lain apa yang seseorang lakukan pada orang lain maka pada akhirnya dia akan mengenai dirinya sendiri. Keyakinan ini membuat seseorang akan senantiasa melakukan perbuatan baik pada orang lain karena pada hakekatnya perbuatan baik yang dilakukan untuk seseorang adalah perbuatan baik untuk dirinya sendiri. Dengan demikian pertukaran timbal balik ini melahirkan kultur yang positif dalam organisasi LPD yakni setiap orang berupaya untuk berbuat baik karena pada hakekatnya perbuatan baik itu dilakukan untuk dirinya sendiri.

Modal sosial terakhir adalah keadilan. Modal sosial ini merupakan modal sosial yang melandasi aktivitas operasional LPD. Modal sosial ini mendorong pengelolaan LPD dilakukan dengan memperhatikan keseimbangan masing-masing pihak yang terlibat sehingga tidak ada satu pihakpun yang merasa dirugikan. Hal ini menjadikan dalam setiap penentuan tata aturan pengelola LPD senantiasa akan meminta pendapat dari segenap krama sehingga seluruh kepentingan dapat terwakili tanpa merugikan LPD.

\section{PENUTUP}

Sebagai lembaga keuangan milik desa pakraman pendirian LPD tidak dapat dipisahkan dari dorongan penguasa supra desa maupun kebutuhan krama desa pakraman akan sebuah lembaga keuangan. Dorongan penguasa supra desa ini dapat dilihat dari adanya peraturan daerah yang dikeluarkan untuk memberi dasar hukum bagi pendirian LPD sekaligus mengatur aktivitas operasionalnya. Selain melalui penetapan peraturan daerah, dorongan penguasa supra desa bagi desa pakraman untuk membentuk LPD adalah dengan diberikannya bantuan permodalan awal yang dapat dijadikan sumber daya pertama bagi pengurus dalam mengelola LPD.

Selain dorongan dari penguasa supra desa, pola perekonomian krama desa pakraman yang sangat dipengaruhi ole ideologi pasar yang bersifat individualitik juga membuat kebutuhan akan lembaga keuangan formal menjadi tinggi. Ideologi pasar mendorong seseorang untuk berkonsumsi guna memenuhi keinginannya dan mengabaikan apakah dia membutuhkan barang/jasa tersebut atau tidak. Dalam kondisi seperti ini, seseorang akan mengalami kondisi kekurangan uang tunai secara kronis. Kebutuhan akan uang tunai tidak dapat lagi dipenuhi dengan meminjam kepada perseorangan kerana kondisi masyarakat sudah sedemikian individualistik. Hal inilah yang mendorong masyarakat untuk ikut serta secara sukarela membangun LPD dan menyambut ajakan penguasa supra desa guna mencapai tujuan yang sama.

Dalam aktivitas operasionalnya LPD memiliki struktur organisasi baku berdasarkan Perda yang mengatur LPD. Struktur organisasi ini terdiri dari Kepala LPD, Bendahara, dan Tata Usaha. Ketiga karyawan utama LPD ini kemudian dibantu oleh staff yang 
bertugas dalam aktivitas operasional LPD seperti pertugas keliling, dan tenaga administrasi. Jenis dan jumlah staff ini sangat bervariasi yang disesuaikan dengan aktivitas operasional LPD.

Dalam melaksanakan aktivitasnya LPD diperkuat oleh sembilan unsur modal sosial yang terdiri dari; trust, jaringan sosial, dan pranata sosial. Unsur modal sosial ini dapat bersinergi dengan baik dalam penerapan struktur pengendalian intern sehingga semua pihak yang berinteraksi dengan LPD dapat mematuhi tata aturan yang berlaku sehingga efektivitas dan efesiensi operasional dapat terjaga dan LPD dapat mecapai tujuan pendiriannya.

\section{DAFTAR PUSTAKA}

Atmadja, Nengah Bawa. 1998. Memudarnya Demokrasi Desa: Pengelolaan Tanah Adat, Konversi dan Implikasi Sosial Dan Politik Di Desa Adat Julah Buleleng, Bali (Disertasi Antropologi yang tidak diterbitkan pada Program Pasca Sarjana Universitas Indonesia)

Bodnar, George H. and William S. Hopwood. 2004. Accounting Information System. Singapore: Pearson Education.
Bungin, Burhan. 2001. Imaji Media Massa. Konstruksi dan Makna Realitas Sosial Iklan Televisi. Yogyakarta: Penerbit Jendela.

Chaney, David. 1996. Lifestyle. Sebuah Pengantar Komprehensif. [Penerjemah: Nuraeni. Yogyakarta: Jalasutra.

Hartadi, Bambang. 1999. Sistem Pengendalian Intern dalam Hubungannya dengan Manajemen dan Audit. Yogyakarta: BPFE.

Lull, James. 1993. Media Komunikasi Kebudayaan: Suatu Pengantar Kebudayaan. [Penerjemah: A. Setiawan Abadi]. Jakarta: Yayasan Obor Indonesia.

Lury, Celia. 1998. Budaya Konsumen [Penerjemah: Hasti T. Champion]. Jakarta: Yayasan Obor Indonesia.

Miles dan Huberman. 1992. Analisis Data Kualitatif Buku Sumber tentang Metode-metode Baru. Jakarta: UI Press.

Munawir, S. 2005. Auditing Modern. Yogyakarta: BPFE

Rama, Dasaratha V. and Frederick L. Jones. $2006 . \quad$ Accounting Information System. Canada: Thompson South-Western.

Piliang, Yasraf Amir. 2004. Postrealitas Realitas Kebudayaan dalam Era Posmetafisika. Yogyakarta: Jalasutra. 